\title{
ВПЛИВ КОМОРБІДНИХ СТАНІВ НА ВИЖИВАНІСТЬ ЧОЛОВІКІВ, ХВОРИХ НА РАК ГОРТАНІ, - ПІДСУМКИ ДЕСЯТИРІЧНОГО СПОСТЕРЕЖЕННЯ
}

\author{
Тернопільський національний медичний університет \\ імені І. Я. Горбачевського МОЗ України, м. Тернопіль, Україна
}

\begin{abstract}
Мета: вивчити вплив коморбідних захворювань на виживаність чоловіків, хворих на рак гортані, залежно від віку.
Матеріали і методи. У роботі використано епідеміологічний, медико-статистичний та аналітичний методи. Проаналізовано базу даних «Лікарняний канцер-реєстр» Комунального некомерційного підприємства «Тернопільський обласний клінічний онкологічний диспансер» Тернопільської обласної ради та базу даних Тернопільського обласного статистичного управління про чисельність та смертність населення області за період 2009-2019 рр. На основі розрахованого індексу коморбідних станів за Charlson (1987) і даних офріційної обліковозвітної документації «Звіти лікувально-профрілактичного закладу» (форма № 20) проведено аналіз виживаності хворих на рак гортані чоловіків, які перебували на стаціонарному лікуванні у Тернопільському обласному клінічному онкологічному диспансері.

Результати. Методом множинних оцінок (за Капланом - Майєром) проаналізовано фрунцію виживаності хворих на рак гортані за період 2009-2019рр. Встановлено, що медіана виживаності у загальній групі хворих на рак гортані чоловіків склала 914 днів від дати встановлення діагнозу, а 25 і 75 процентилі виживаності склали, відповідно, 365 і 1986 днів. У групі хворих на рак гортані чоловіків, молодших 60 років, медіана виживаності становила 580 днів, а в групі старших за 60 років - 578 днів (без істотної відмінності). Проте порівняльний статистичний аналіз виживаності за F-критерієм Кокса вказав на істотну статистичну різницю у виживаності хворих на рак гортані чоловіків, старших 60 років, з високим індексом коморбідності, порівняно з групою чоловіків, молодших 60 років, 3 низьким індексом коморбідності.

Висновки. Кумулятивна частка виживаності хворих на рак гортані чоловіків залежить від супутньої патології, виявленої на час встановлення діагнозу. Тривалість виживаності хворих на рак гортані чоловіків, старших 60 років, з високим індексом коморбідності менша, порівняно з групою чоловіків, молодших 60 років, з низьким індексом коморбідності.

Хворі на рак гортані чоловіки, старші 60 років, з високим індексом коморбідності потребують розробки спеціальних лікувальних тактик з урахуванням виявленої коморбідної патології.
\end{abstract}

КЛЮчОВІ СЛОВА: рак гортані; індекс коморбідності; чоловіки; вік; аналіз виживаності за Капланом Майєром.

Епідеміологічні дані свідчать про те, що захворюваність на рак гортані у Центральній і Східній Європі є найвищою у світі серед чоловіків - 7,6 випадку на 100 тис. населення (світовий стандарт). Для порівняння: у Південній Європі - 5,4, Західній Європі - 3,6, Північній Європі - 3,2 та загалом у світі - 3,6 випадку [15, 16, 19, 22]. За даними канцер-реєстру США, загальна 5-річна виживаність хворих на рак гортані становить $61 \%$, а при локалізованій формі раку - 78 \% [6, 7].

В Україні захворюваність на рак гортані у чоловіків становила 7,8 випадку на 100 тис. населення (світовий стандарт) у 2016 р. і 7,1 в 2019 р., а смертність: 4,4 (2016) і 4,0 (2019) відповідно. Упродовж одного року 3 моменту встановлення діагнозу помирає 25,2-28,5 \% хворих. Захворюваність і смертність чоловіків, хворих на рак гортані, значно зростають у віці після 50 років. Наприклад, у 2016 р. у віковій групі 50-54 роки показники «захворюваність/смертність» становили 21,4/8,5 (на 100 тис. чоловічого населення); 55-59 років - 37,4/20,0; 60-64 роки - 43,6/24,0;

(c) І. В. Жулкевич, Л. М. Скакун, І. И. Галайчук, 2021
65-69 років - 50,7/27,8. Схоже співвідношення цих показників було і в 2019 р.: вікова група 5054 роки - 18,9/8,9; 55-59 років - 30,4/13,3; 6064 роки - 40,5/22,6; 65-69 років - 44,2/30,7 [3, 4].

Таким чином, вік пацієнта $€$ серйозним фрактором ризику. Імовірно, нашарування коморбідних захворювань, пов'язаних із віком, впливає на перебіг раку гортані. Це питання ще не вивчене і в спеціальній літературі відображене частково [5, $8,20]$. Проте бібліосемантичний аналіз, аналіз наукових статей в наукометричній базі даних медичних і біологічних публікацій, створеній Національним центром біотехнологічної інорормації (NCBI) Національної медичної бібліотеки США (NLM) PUBMED, вказують на «ренесанс» інтересу науковців до впливу коморбідних станів щодо онкохворих [1, 2, 9, 12, 13], зокрема їх виживаності [10, 14].

Мета дослідження: на основі ретропроспективного дослідження вивчити вплив коморбідних захворювань на виживаність чоловіків, хворих на рак гортані, залежно від віку.

Матеріали і методи. Виходячи з поставленої мети дослідження, сорормовано запит до 
двох систем збереження інорормації - бази даних «Лікарняний канцер-реєстр» Комунального некомерційного підприємства «Тернопільський обласний клінічний онкологічний диспансер» Тернопільської обласної ради (ТОКОД) та бази даних Тернопільського обласного статистичного управління про чисельність та смертність населення області за період 2009-2019 рр.

Обидві бази об'єднано, завдяки чому отримано обрахункову базу даних, що містила таку інфрормацію: паспортні дані хворих на рак гортані, стать, час встановлення діагнозу, гістологічне дослідження біопсійного матеріалу з пухлини гортані, класифрікований за TNM діагноз, стадію захворювання і клінічну групу, а також наявність супутньої патології й статус цензурованості хворого (живий чи помер). Наявність і верифрікація супутньої патології ґрунтувались на консультативних заключеннях профрільних спеціалістів та анамнестичних даних.

Два незалежні лікарі-експерти провели оцінку коморбідних станів за Charlson (1987) [23] у хворих на рак гортані чоловіків, які перебували на стаціонарному лікуванні в ТОКОД, на основі даних офріційної обліково-звітної документації ТОКОД «Звіти лікувально-профрілактичного закладу» (форма № 20). Критерієм включення хворого в подальше статистичне дослідження був повний збіг розрахованого індексу коморбідності двома незалежними лікарями-експертами.

Діагностика раку гортані ґрунтувалась на клінічних даних і результатах інструментальних методів дослідження на основі діючих протоколів надання медичної допомоги хворим на рак гортані ТОКОД (пряма і непряма ларингоскопія, рентгенографрія або КТ органів грудної порожнини і шиї, УЗД лімфатичних вузлів шиї, УЗД органів черевної порожнини тощо).

Морфологічна верифрікація діагнозу ґрунтувалась на гістологічному дослідженні біопсійного матеріалу з пухлини гортані.

Для статистичного аналізу загальної виживаності застосовували статистичний пакет Statistiса 6.0 .

Результати дослідження та їх обговорення. У Тернопільському обласному клінічному онкологічному диспансері за період 2009-2019 рр. перебували на обстеженні та лікуванні 576 хворих на рак гортані, зокрема 561 (97\%) чоловіка віком від 36 до 88 років та 15 (3 \%) жінок віком від 31 до 83 років.

Здобуті дані про гендерні відмінності в загальній групі хворих на рак гортані відповідають даним дослідження, проведеного в Люблінській області Польщі [12], в якому також встановлено, що поширеність раку гортані серед жінок була значно нижчою порівняно з чоловіками, до того ж подібні гендерні особливості зазначають й інші автори [14, 17, 21]. Проте в дослідженні, проведеному в Данії, автори вказують на іншу гендерну картину серед хворих на рак гортані - 82 \% чоловіків і $18 \%$ жінок [11].
Серед відомостей про 561 чоловіка, хворого на рак гортані, коректних записів, щоб задовольняли всі критерії включення хворого в подальше статистичне дослідження із вивчення впливу коморбідних захворювань на загальну виживаність хворих на рак гортані залежно від віку, лише 475. Тому в статистичне дослідження включено 475 чоловіків, хворих на рак гортані.

Методом описової статистики встановлено, що в групі чоловіків, хворих на рак гортані, гістограма вікового розподілу мала такі характеристики: середнє значення віку хворих на час встановлення діагнозу раку гортані - 60,58 року; медіана - 59 років (мінімальний вік - 36 років, максимальний вік - 88 років). Наведені дані відповідали нормальному статистичному розподілу віку в обстеженій групі чоловіків, хворих на рак гортані (рис. 1).

Дані, які ми здобули, щодо середнього значення віку хворих чоловіків на час встановлення діагнозу раку гортані (60,58 року) і медіана розподілу віку - 59 років відповідають даним інших дослідників $[11,18]$.

У підсумку обговорення даних, здобутих у нашому дослідженні, щодо гендерного складу і вікових характеристик хворих, які перебували на стаціонарному лікуванні в ТОКОД у 20092019 рр., варто визначити їх валідність відносно раніше опублікованих досліджень.

Методом множинних оцінок (за Капланом Майєром) проаналізовано фрункцію загальної виживаності хворих на рак гортані, які перебували на стаціонарному лікуванні в ТОКОД у 2009-2019 рр., кількість спостережень - 468 (нецензурованих - 293 (62,61 \%), цензурованих 175 (37,39 \%)). Встановлено, що медіана виживаності в загальній групі чоловіків, хворих на рак гортані, склала 914 днів від дати встановлення діагнозу, а 25 і 75 процентилі виживаності склали, відповідно, 365 і 1986 днів (рис. 2).

Таким чином, проаналізовано виживаність чоловіків, хворих на рак гортані, які перебували на стаціонарному лікуванні в ТОКОД у 20092019 рр., у двох вікових групах - молодших і старших 60 років (рис. 3).

У групі чоловіків, хворих на рак гортані, молодших 60 років медіана виживаності склала 580 днів, а у групі старших 60 років - 578 днів. Кількість спостережень в загальній групі - 468, нецензурованих - 293 (62,61 \%), цензурованих $175(37,39 \%)$, а в групах хворих на рак гортані молодших і старших 60 років - нецензурованих спостережень - 146 (61,60 \%) і 147 (63,64 \%) і цензурованих, відповідно, 91 (38,40 \%) і 84 (36,36\%). Порівняльний статистичний аналіз виживаності за F-критерієм Кокса не вказав на достовірну статистичну різницю виживаності в групах чоловіків, хворих на рак гортані, молодших та старших 60 років.

Проте результати порівняння виживаності в групах чоловіків, хворих на рак гортані, які перебували на стаціонарному лікуванні в ТОКОД у 


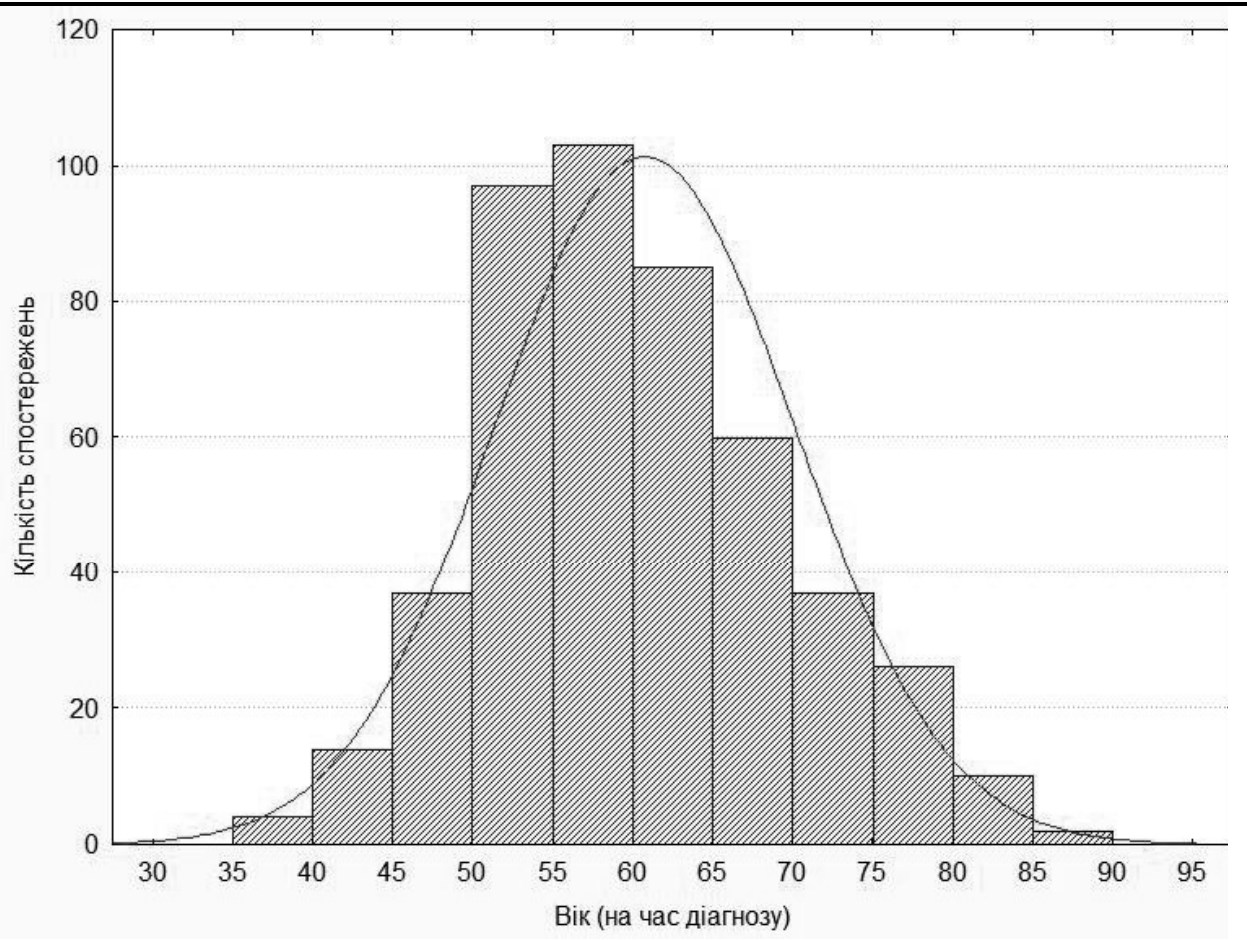

Рuc. 1. Гістограма розподілу віку в групі обстежених чоловіків, хворих на рак гортані.

Функція виживаності чоловіків, хворих на рак гортані

о Завершено + Цензуровано

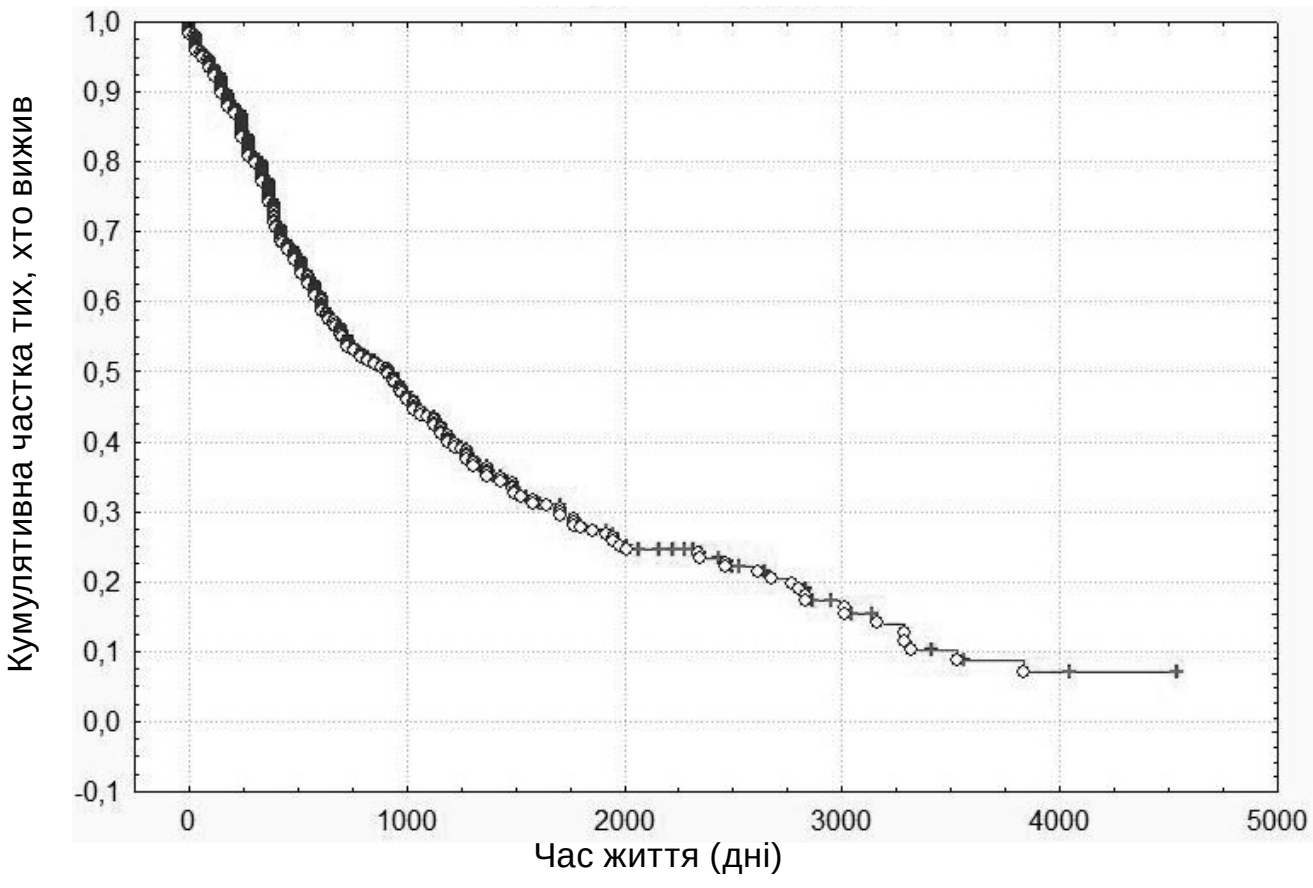

Рuс. 2. Функція виживаності чоловіків, хворих на рак гортані, які перебували на стаціонарному лікуванні в ТОКОД у 2009-2019 рр.

2009-2019 рр. залежно від індексу коморбідності за Charlson, дозволили виявити, що медіана виживаності коливалася в межах 549-638 днів від часу встановлення діагнозу (рис. 4, табл. 1), й візуалізувати суми внесків високого і низького індексу коморбідності в двох вікових групах (рис. 5).
Усе наведене спонукало нас вивчити кумулятивну частку чоловіків, хворих на рак гортані, які вижили, залежно від віку (молодших і старших 60 років) та індексу коморбідності за Charlson (до 4 балів - низький, більше 4 балів - високий). Дані аналізу - 219 допустимих спостережень 
Кумулятивна частка чоловіків, хворих на рак гортані, які вижили у двох вікових групах о Завершено + Цензуровано

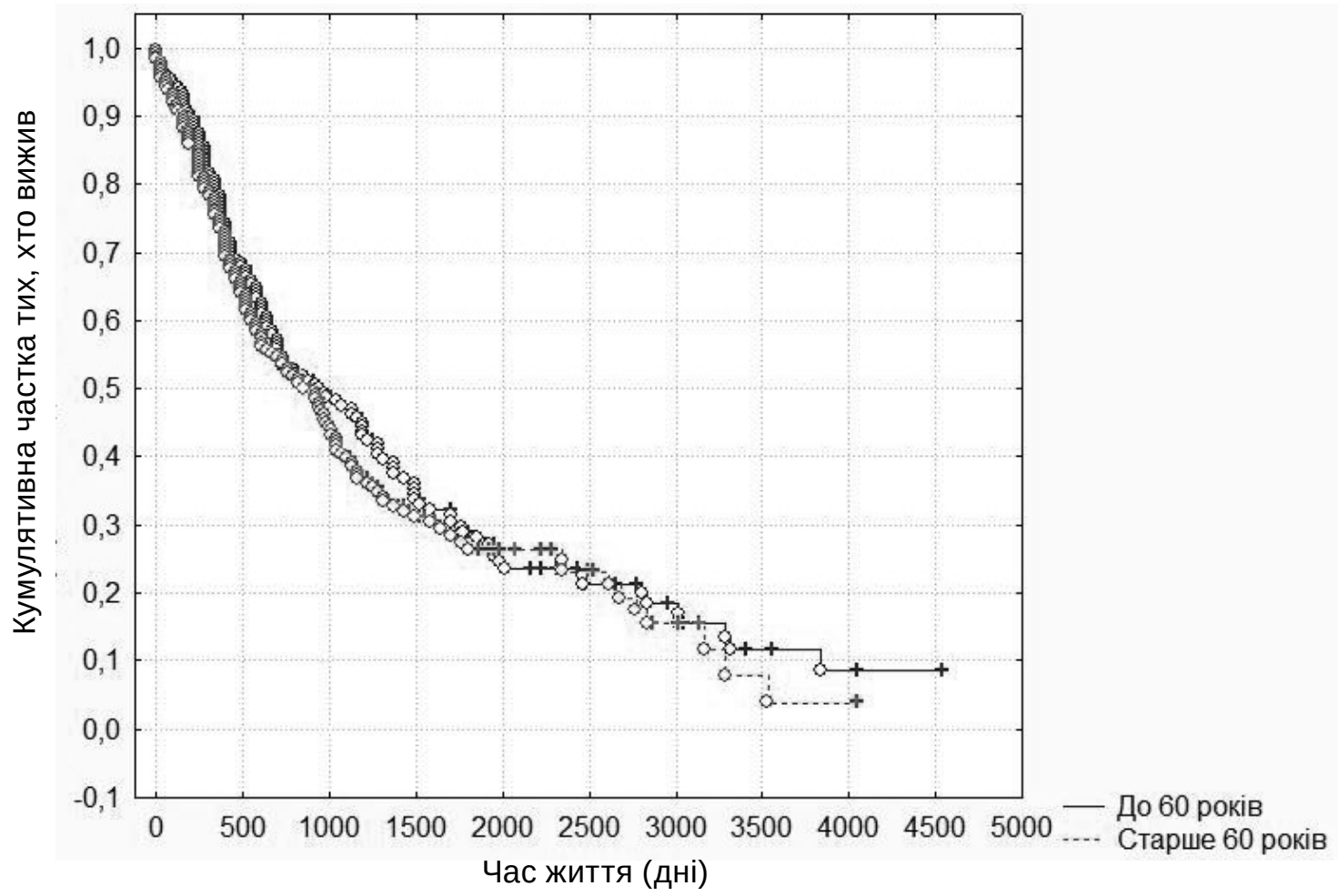

Рuc. 3. Кумулятивна частка чоловіків, хворих на рак гортані, які вижили, що перебували на стаціонарному лікуванні в ТОКОД у 2009-2019 рр., у двох групах - молодших і старших 60 років.

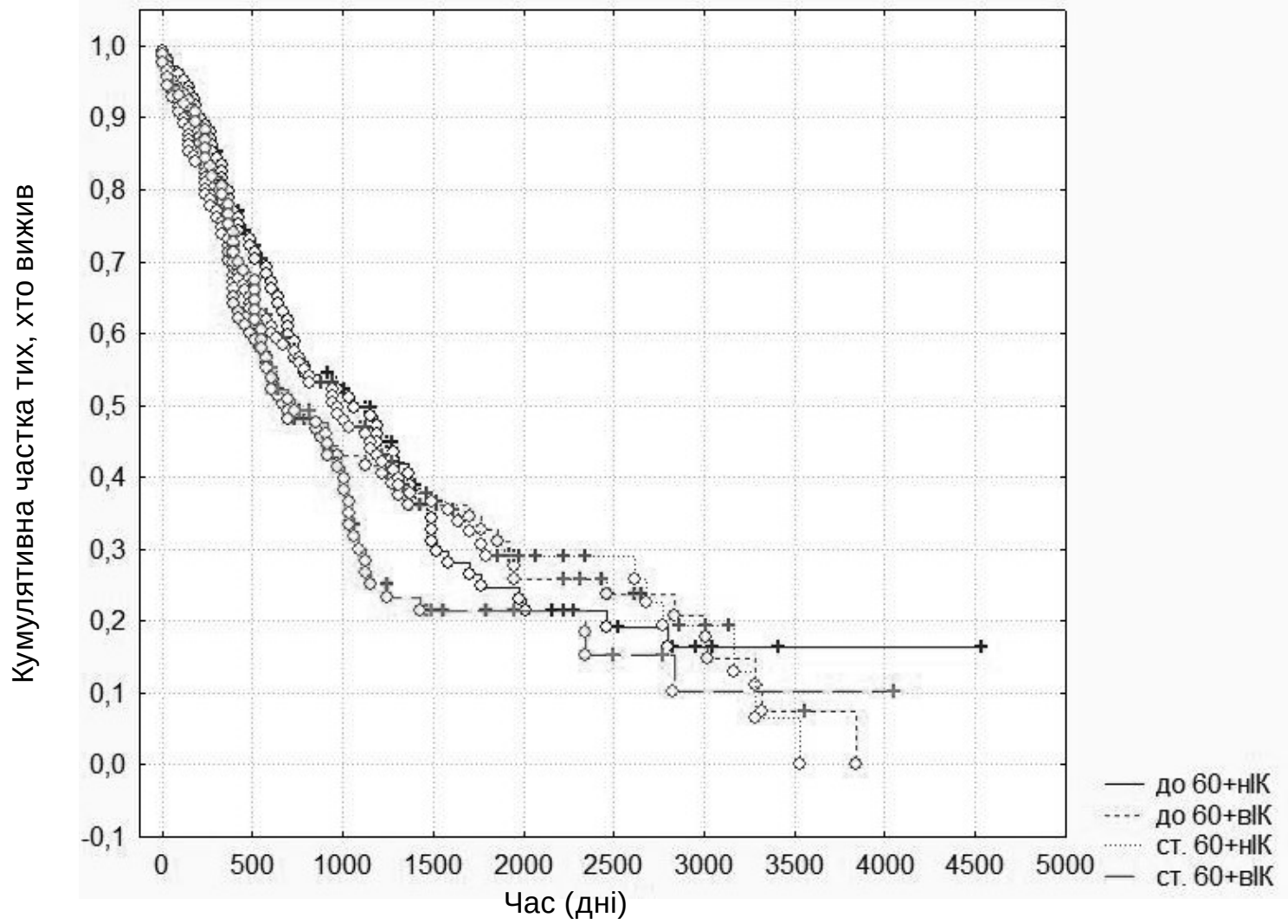

Puc. 4. Кумулятивна частка чоловіків, хворих на рак гортані, які вижили, що перебували на стаціонарному лікуванні в ТОКОД у 2009-2019 рр., залежно від віку та індексу коморбідності за Charlson. 
Таблиця 1. Медіана виживаності в групах чоловіків, хворих на рак гортані, залежно від індексу коморбідності за Charlson

\begin{tabular}{|c|c|c|c|c|}
\hline$\stackrel{\text { ㅁ }}{\stackrel{2}{2}}$ & 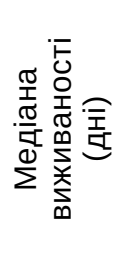 & 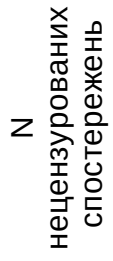 & 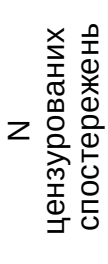 & 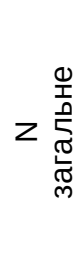 \\
\hline $\begin{array}{l}\text { Молодших } \\
60 \text { років, } \\
\text { низький Ік }\end{array}$ & 609 & 73 & 57 & 130 \\
\hline $\begin{array}{l}\text { Молодших } \\
60 \text { років, } \\
\text { високий ІІ }\end{array}$ & 577 & 73 & 33 & 106 \\
\hline $\begin{array}{l}\text { Старших 60, } \\
\text { низький ІК }\end{array}$ & 638 & 88 & 55 & 143 \\
\hline $\begin{array}{l}\text { Старших 60, } \\
\text { високий IK }\end{array}$ & 549 & 59 & 30 & 89 \\
\hline
\end{tabular}
нецензурованих - 73 (56,15\%), цензурованих $57(43,85 \%))$. У групі обстежених чоловіків, хворих на рак гортані, старших 60 років, із високим індексом коморбідності за Charlson (89 хворих нецензурованих - 59 (66,71 \%), цензурованих $30(33,71 \%))$. Отримані результати наведено на рисунку 6.

Аналіз даних за F-критерієм Кокса $(p=0,039)$ вказав на достовірну статистичну різницю у виживаності хворих на рак гортані в групах хворих молодших і старших 60 років залежно від індексу коморбідності за Charlson - виживаність чоловіків, хворих на рак гортані, старших 60 років, із високим індексом коморбідності статистично нижча, порівняно $з$ групою чоловіків, молодших 60 років, з низьким індексом коморбідності.

Здобуті дані свідчать про залежність виживаності чоловіків, хворих на рак гортані, від виявленої супутньої патології, причому загальна виживаність найменша в групі чоловіків, старших 60 років, з високим індексом коморбідності

(нецензурованих - 132 (60,27 \%), цензурованих $87(39,73 \%))$. У групі обстежених чоловіків, хворих на рак гортані, молодших 60 років, із низьким (549 днів), а найбільша - в групі чоловіків, молодших 60 років, 3 низьким індексом коморбідності (638 днів), що складає 89 днів (2,9 місяця).

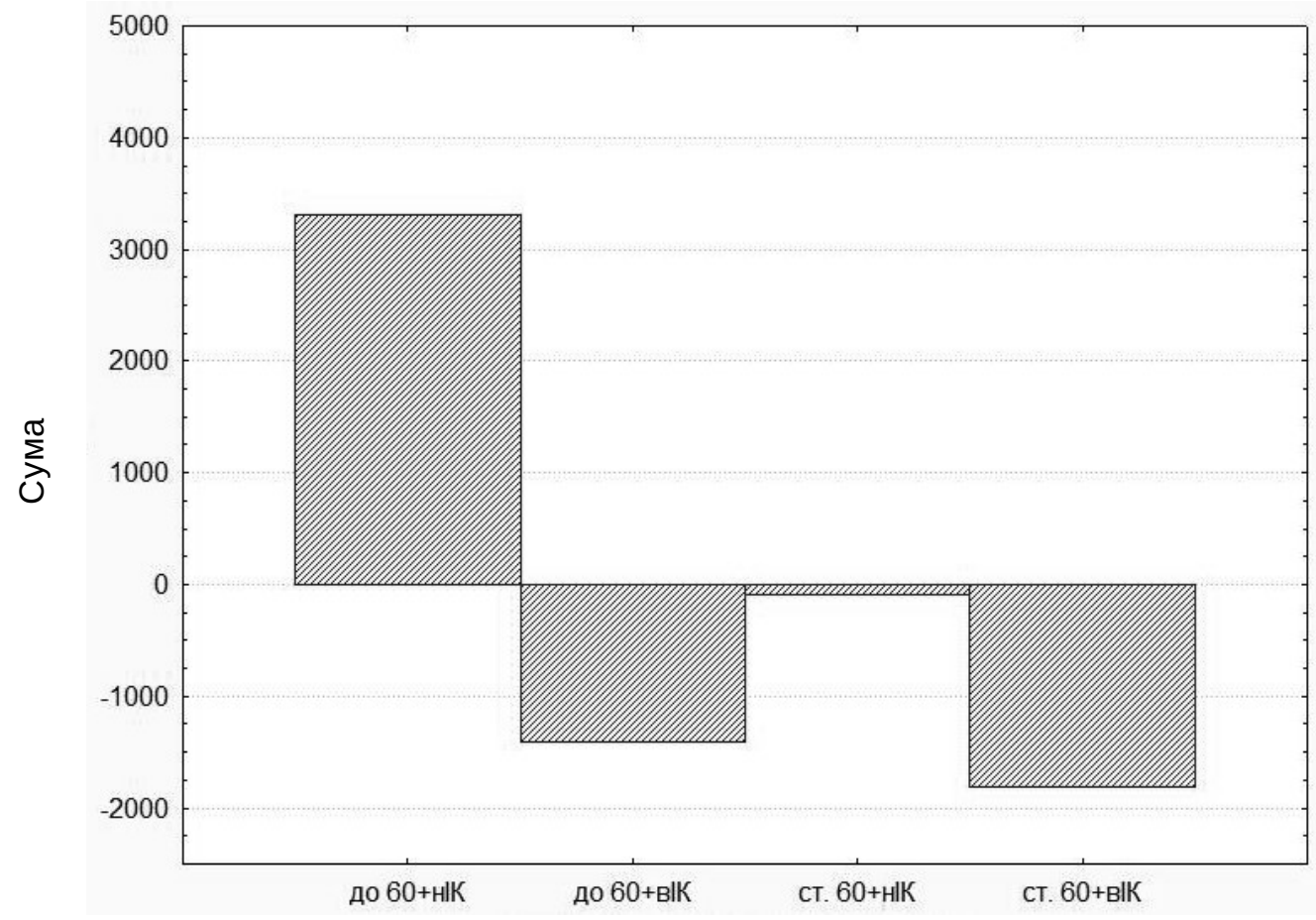

Групи чоловіків, хворих на рак гортані

Puc. 5. Суми внесків високого і низького індексу коморбідності у виживаність чоловіків, хворих на рак гортані, в двох вікових групах.

\section{Висновки}

1. Кумулятивна частка чоловіків, хворих на рак гортані, які вижили, залежить від супутньої патології, виявленої на час встановлення діагнозу.

2. Час виживаності чоловіків, хворих на рак гортані, старших 60 років, 3 високим індексом коморбідності, порівняно з групою чоловіків, молодших 60 років, з низьким індексом коморбідності, нижчий.

3. Чоловіки, хворі на рак гортані, старші 60 років, 3 високим індексом коморбідності потребують розробки спеціальних лікувальних тактик з урахуванням виявленої коморбідної патології. 


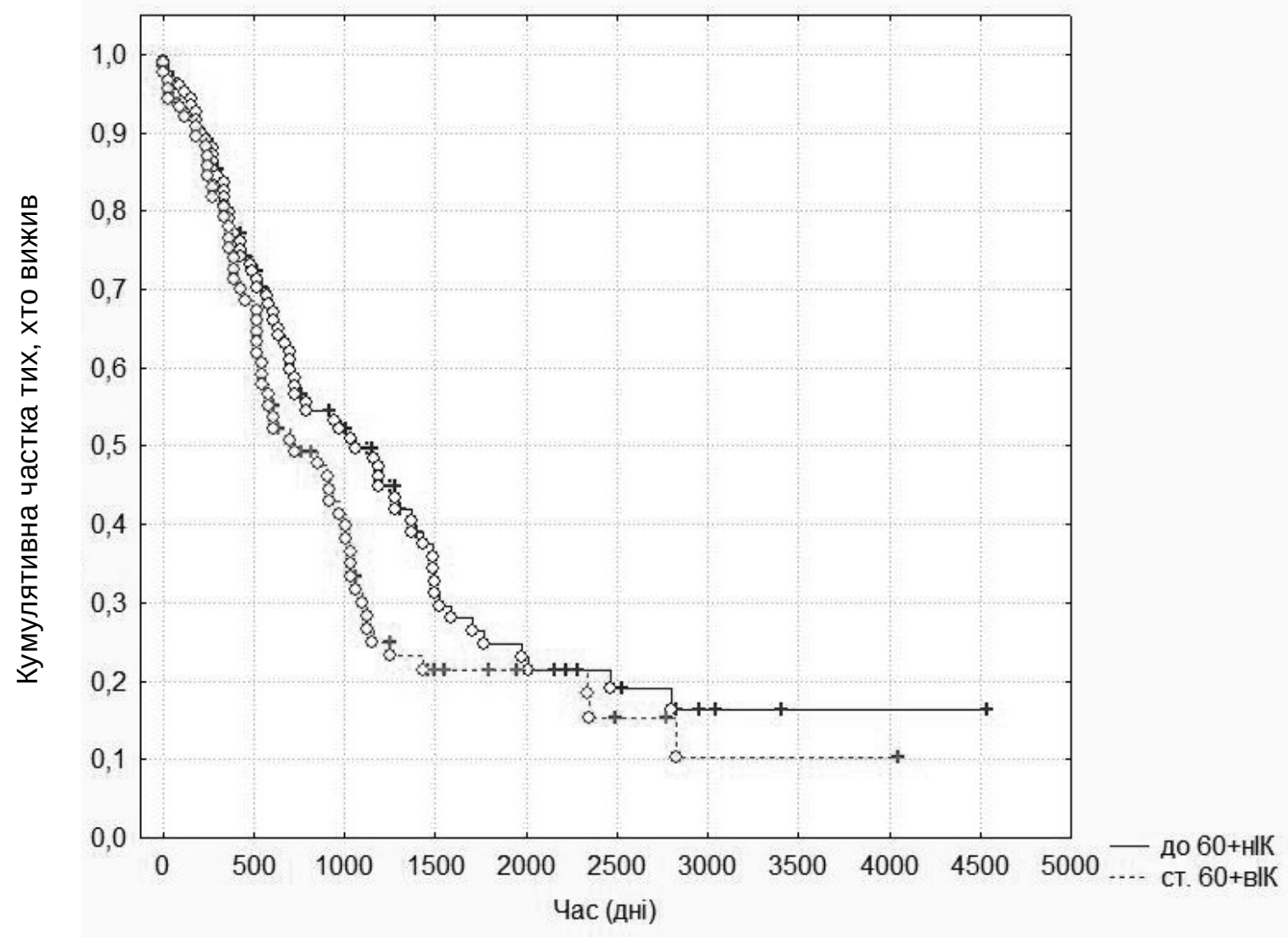

Puc. 6. Кумулятивна частка чоловіків, хворих на рак гортані, які вижили, залежно від віку (молодших і старших 60 років) та індексу коморбідності (низький чи високий) за Charlson.

Перспективи подальших досліджень. По- рих на рак гортані, з високим і низьким індексом дальші дослідження будуть спрямовані на коморбідності в різних вікових групах залежно вивчення загальної виживаності чоловіків, хво- від використаних лікувальних тактик.

\section{Список літератури}

1. Бореліозна лімфаденопатія у практиці онколога (клінічні спостереження) / І. Й. Галайчук, І. В. Жулкевич, С. І. Сміян [та ін.] // Онкологія. - 2019. - № 21 (3). - С. 250-253.

2. Жулкевич І. В. Первинна легенева лімфома з бронхоасоційованої лімфоїдної тканини (клінічне спостереження) / І. В. Жулкевич, І. Й. Галайчук // Патологія. - 2019. - № 16 (2). - С. 293-298.

3. Рак в Україні, 2016-2017. Захворюваність, смертність, показники діяльності онкологічної служби [Електронний ресурс] / [3. П. Федоренко, Л. О. Гулак, Ю. Й. Михайлович та ін.] // Бюлетень Національного канцер-реєстру України. 2018. - № 19. - Режим доступу : www.ncru.inf.ua/publications/BULL_19/index.htm.

4. Рак в Україні, 2019-2020. Захворюваність, смертність, показники діяльності онкологічної служби [Електронний ресурс] / [3. П. Федоренко, Ю. Й. Михайлович, Л. О. Гулак та ін.] // Бюлетень Національного канцер-реєстру України. 2021. - № 22. - Режим доступу : www.ncru.inf.ua/publications/BULL_22/index.htm.

5. Age-adjusted comorbidity and survival in locally advanced laryngeal cancer / C. F. Mulcahy, A. S. R. Mohamed, A. Kanwar [et al.] // Head Neck. - 2018. - Vol. 40 (9). - P. 2060-2069.

6. An update on larynx cancer / C. E. Steuer, M. El-Deiry, J. R. Parks [et al.] // CA Cancer. J. Clin. - 2017. - Vol. 67 (1). P. 31-50.

7. Cancer Facts \& Figures 2021. - Atlanta: American Cancer Society, 2021. - 72 p.

8. Comorbid predictors of poor response to chemoradiotherapy for laryngeal squamous cell carcinoma / M. Hu, F. Ampil, C. Clark [et al.] // Laryngoscope. - 2012. - Vol. 122 (3). - P. 565-571.

9. Effects of tumour stage, comorbidity and therapy on survival of laryngeal cancer patients: a systematic review and a meta-analysis / E. Rudolph, G. Dyckhoff, H. Becher [et al.] // Eur. Arch. Otorhinolaryngol. - 2011. - Vol. 268 (2). - P. $165-179$. 10. Factors predicting survival in patients with early stage laryngeal cancer: A cohort study between 2000 to 2015 / M. Fararouei, N. Daneshi, M. Mohammadianpanah [et al.] // J. BUON. - 2017. - Vol. 22 (4). - P. 996-1003.

11. Incidence and survival of laryngeal cancer in Denmark: a nation-wide study from 1980 to 2014 / A. Nahavandipour, K. K. Jakobsen, C. Grønhøj [et al.] // Acta Oncol. - 2019. - Vol. 58 (7). - P. 977-982.

12. Laryngeal cancer in farmers from Lublin region of Poland / K. Morshed, M. Szymański, H. Siwiec, W. Gołabek // Ann. Agric. Environ. Med. - 2008. - Vol. 15 (1). - P. 13-19.

13. Laryngeal cancer in Kazakhstan - ethnic, age and gender differences over time / N. Igissinov, V. Zatoskikh, M. A. Moore [et al.] // Asian Pac. J. Cancer Prev. - 2013. - Vol. 14 (11). - P. 7033-7038. 
14. Laryngeal cancer incidence and mortality in China, 2010 / S. S. Zhang, Q. M. Xia, R. S. Zheng, W. Q. Chen // J. Cancer. Res. Ther. - 2015. - Vol. 11 (Suppl. 2). - P. 143-148.

15. Laryngea/ cancer mortality trends in European countries / L. Chatenoud, W. Garavello, E. Pagan [et al.] // Int. J. Cancer. 2016. - Vol. 138 (4). - P. 833-842.

16. Laryngeal cancer: United Kingdom National Multidisciplinary guidelines / T. M. Jones, M. De, B. Foran [et al.] // J. Laryngol. Otol. - 2016. - Vol. 130 (S2). - P. S75-S82.

17. Matos J. P. Causes of death in patients with laryngeal cancer in stages I and II / J. P. Matos, J. Castro Silva, E. Monteiro // Acta Med. Port. - 2012. - Vol. 25 (5). - P. 317-322.

18. Subglottic squamous cell carcinoma in Denmark 1971-2015 - a national population-based cohort study from DAHANCA, the Danish Head and Neck Cancer group / L. Hill-Madsen, C. A. Kristensen, E. Andersen [et al.] // Acta Oncol. - 2019. Vol. 58 (10). - P. 1509-1513.

19. World Health Organization. The Global Cancer Observatory, 2020. - URL : https://gco.iarc.fr/today/data/factsheets/ populations/900-world-fact-sheets.pdf.

20. The significance of comorbidity in advanced laryngeal cancer / A. Y. Chen, L. K. Matson, D. Roberts, H. Goepfert // Head Neck. - 2001. - Vol. 23 (7). - P. 566-572.

21. Trends in laryngeal cancer mortality in Europe / C. Bosetti, W. Garavello, F. Levi [et al.] // Int. J. Cancer. - 2006. Vol. 119 (3). - P. 673-681.

22. Updates on larynx cancer epidemiology / R. Nocini, G. Molteni, C. Mattiuzzi, G. Lippi // Chin. J. Cancer Res. - 2020. Vol. 32 (1). - P. 18-25.

23. Validation of a combined comorbidity index / M. Charlson, T. P. Szatrowski, J. Peterson, J. Gold // J. Clin. Epidemiol. 1994. - Vol. 47 (11). - P. 1245-1251.

\section{References}

1. Galaychuk, I.Yo., Zhulkevych, I.V., Smiyan, S.I., Nykolyuk, V.D., \& Komorovsky, R.R. (2019). Boreliozna limfadenopatiia u praktytsi onkoloha (klinichni sposterezhennia) [Borrelious lymphadenopathy in oncology practice (clinical observations)]. Onkolohiia - Oncology, 21, 3 [in Ukrainian]. DOI: 10.32471/oncology.2663-7928.t-21-3-2019-g.7896. Retrieved from: https://www.oncology.kiev.ua/article/7896/boreliozna-limfadenopatiya-u-prakticionkologa-klinichni-sposterezhennya.

2. Zhulkevych, I.V., \& Halaichuk, I.Yo. (2019). Pervynna leheneva limfoma z bronkhoasotsiyovanoi limfoidnoi tkanyny (klinichne sposterezhenna) [Primary pulmonary lymphoma from bronchus-associated lymphoid tissue (clinical observation)]. Pathologia, 16 (2), 293-298 [in Ukrainian].

3. Fedorenko, Z.P., Hulak, L.O., Mykhailovych, Yu.Y., Horokh, Ye.L., Ryzhov, A.Yu., Sumkina, O.V., \& Kutsenko, L. (2018). Rak v Ukraini, 2016-2017. Zakhvoriuvanist, smertnist, pokaznyky diialnosti onkolohichnoi sluzhby [Cancer in Ukraine, 2016-2017. Incidence, mortality, indicators for activities of the oncological service]. Biuleten Natsionalnoho kantserreiestru Ukrainy - Bulletin of the National Cancer Registry of Ukraine, 19. Retrieved from: www.ncru.inf.ua/publications/ BULL_19/index.htm. [in Ukrainian].

4. Fedorenko, Z., Michailovich, Yu., Goulak, L., Gorokh, Ye., Ryzhov, A., Soumkina, O., \& Koutsenko, L. (2021). Rak v Ukraini, 2019-2020. Zakhvoriuvanist, smertnist, pokaznyky diialnosti onkolohichnoi sluzhby [Cancer in Ukraine, 20192020. Incidence, mortality, indicators for activities of the oncological service]. Biuleten Natsionalnoho kantser-reiestru Ukrainy - Bulletin of the National Cancer Registry of Ukraine, 22. Retrieved from: www.ncru.inf.ua/publications/BULL_22/ index.htm. [in Ukrainian].

5. Mulcahy, C.F., Mohamed, A.S.R., Kanwar, A., Hutcheson, K.A., Ghosh, A., Vock, D., ..., \& Fuller, C.D. (2018). Ageadjusted comorbidity and survival in locally advanced laryngeal cancer. Head Neck, 40 (9), 2060-2069. DOI: https://doi. org/10.1002/hed.25200.

6. Steuer, C.E., El-Deiry, M., Parks, J.R., Higgins, K.A., \& Saba, N.F. (2017). An update on larynx cancer. CA Cancer. J. Clin., 67 (1), 31-50. DOI: 10.3322/caac.21386.

7. (2021). Cancer Facts \& Figures 2021. Atlanta: American Cancer Society.

8. Hu, M., Ampil, F., Clark, C., Sonavane, K., Caldito, G., \& Nathan, C.A. (2012). Comorbid predictors of poor response to chemoradiotherapy for laryngeal squamous cell carcinoma. Laryngoscope, 122 (3), 565-571. DOI: 10.1002/lary.22489. 9. Rudolph, E., Dyckhoff, G., Becher, H., Dietz, A., \& Ramroth, H. (2011). Effects of tumour stage, comorbidity and therapy on survival of laryngeal cancer patients: a systematic review and a meta-analysis. Eur. Arch. Otorhinolaryngol., 268 (2), 165-179. DOI: 10.1007/s00405-010-1395-8.

10. Fararouei, M., Daneshi, N., Mohammadianpanah, M., Reza Tabatabaei, H., Zare-Bandamiri, M., \& Dianatinasab, M. (2017). Factors predicting survival in patients with early stage laryngeal cancer: A cohort study between 2000 to 2015. J. BUON, 22 (4), 996-1003.

11. Nahavandipour, A., Jakobsen, K.K., Grønhøj, C., Hebbelstrup Jensen, D., Kim Schmidt Karnov, K., Klitmøller Agander, T., \& von Buchwald, C. (2019). Incidence and survival of laryngeal cancer in Denmark: a nation-wide study from 1980 to 2014. Acta Oncol., 58 (7), 977-982. DOI: 10.1080/0284186X.2019.1572923.

12. Morshed, K., Szymański, M., Siwiec, H., \& Gołabek, W. (2008). Laryngeal cancer in farmers from Lublin region of Poland. Ann. Agric. Environ. Med., 15 (1), 13-19.

13. Igissinov, N., Zatoskikh, V., Moore, M.A., Igissinov, S., Aldiyarova, G., Tokmurziyeva, G., \& Sarsenova, S. (2013). Laryngeal cancer in Kazakhstan - ethnic, age and gender differences over time. Asian Pac. J. Cancer Prev., 14 (11), $7033-$ 7038. DOI: 10.7314/apjcp.2013.14.11.7033.

14. Zhang, S.S., Xia, Q.M., Zheng, R.S., \& Chen, W.Q. (2015). Laryngeal cancer incidence and mortality in China, 2010. J. Cancer. Res. Ther., 11 (2), C143-148. DOI: 10.4103/0973-1482.168175. 
15. Chatenoud, L., Garavello, W., Pagan, E., Bertuccio, P., Gallus, S., La Vecchia, C., \& Bosetti, C. (2016). Laryngeal cancer mortality trends in European countries. Int. J. Cancer, 138 (4), 833-842. DOI: 10.1002/ijc.29833.

16. Jones, T.M., De, M., Foran, B., Harrington, K., \& Mortimore, S. (2016). Laryngeal cancer: United Kingdom National Multidisciplinary guidelines. J. Laryngol. Otol., 130 (S2), S75-S82. DOI: 10.1017/S0022215116000487.

17. Matos, J.P., Castro Silva, J., \& Monteiro, E. (2012). Causes of death in patients with laryngeal cancer in stages I and II. Acta Med. Port., 25 (5), 317-322.

18. Hill-Madsen, L., Kristensen, C.A., Andersen, E., Johansen, J., Andersen, L.J., Primdahl, H., \& Lyhne, N.M. (2019). Subglottic squamous cell carcinoma in Denmark 1971-2015 - a national population-based cohort study from DAHANCA, the Danish Head and Neck Cancer group. Acta Oncol., 58 (10), 1509-1513. DOI: 10.1080/0284186X.2019.1645355.

19. World Health Organization. (2020). The Global Cancer Observatory. Retrieved from: https://gco.iarc.fr/today/data/ factsheets/populations/900-world-fact-sheets.pdf

20. Chen, A.Y., Matson, L.K., Roberts, D., \& Goepfert, H. (2001). The significance of comorbidity in advanced laryngeal cancer. Head Neck., 23 (7), 566-572. DOI: 10.1002/hed.1079.

21. Bosetti, C., Garavello, W., Levi, F., Lucchini, F., Negri, E., \& La Vecchia, C. (2006). Trends in laryngeal cancer mortality in Europe. Int. J. Cancer, 119 (3), 673-681. DOI: 10.1002/ijc.21855.

22. Nocini, R., Molteni, G., Mattiuzzi, C., \& Lippi, G. (2020). Updates on larynx cancer epidemiology. Chin. J. Cancer Res., 32 (1), 18-25. DOI: 10.21147/j.issn.1000-9604.2020.01.03.

23. Charlson, M., Szatrowski, T.P., Peterson, J., \& Gold, J. (1994). Validation of a combined comorbidity index. J. Clin. Epidemiol., 47 (11), 1245-1251. DOI: 10.1016/0895-4356(94)90129-5.

\section{THE INFLUENCE OF CO-MORBID CONDITIONS ON THE SURVIVAL OF MALE PATIENTS WITH LARYNGEAL CANCER: RESULTS OF TEN YEARS OBSERVATION}

I. V. Zhulkevych, L. M. Skakun, I. Yo. Galaychuk

I. Horbachevsky Ternopil National Medical University, Ternopil, Ukraine

Purpose: to study the effect of co-morbid diseases on the survival of men with laryngeal cancer depending on age.

Materials and Methods. Epidemiological, medical-statistical and analytical methods are used in the work. The databases "Hospital Cancer Register" and the database of the Ternopil Regional Statistical Office on the population and mortality in the region for 2009-2019 were analyzed. Based on the calculated index of co-morbid conditions according to Charlson (1987) and the data of the official Hospital documentation "Report form № 20" the survival of patients with laryngeal cancer who were hospitalized in Ternopil Regional Clinical Oncology Dispensary was analyses.

Results. The survival function of patients with laryngeal cancer for the period 2009-2019 was analyzed by the method of multiple assessments (according to Kaplan-Mayer). It was found that the median survival in the general group of patients with laryngeal cancer was 914 days from the date of diagnosis (laryngeal cancer), and the 25th and 75th percentile of survival were 365 and 1986 days, respectively.

In the group of patients with laryngeal cancer in men younger than 60 years, the median survival was 580 days, and in the group older than 60 years -578 days (without significant difference). However, a comparative statistical analysis of Cox's F-test survival indicated a significant statistical difference in the survival of laryngeal cancer patients over 60 years of age and with a high co-morbidity index compared with the group of men less than 60 years of age and with a low co-morbidity index.

Conclusions. The cumulative survival rate of men with laryngeal cancer depends on the concomitant pathology detected at the time of diagnosis. The survival time of patients with laryngeal cancer in men over 60 years of age and a high co-morbidity index is shorter compared to the group of men less than 60 years and a low co-morbidity index. Male patients with laryngeal cancer older than 60 years and a high co-morbidity index require the elaborate of special treatment tactics, taking into account the identified co-morbid pathology.

KEY WORDS: laryngeal cancer; co-morbidity index; men; age; Kaplan-Mayer survival analysis.

Рукопис надійшов до редакції 12.04.2021 p.

\section{Відомості про авторів:}

Жулкевич Ігор Валентинович - доктор медичних наук, професор, професор кафедри онкології, променевої діагностики і терапії та радіаційної медицини Тернопільського національного медичного університету імені І. Я. Горбачевського МО3 України; тел.: +38(0352) 26-82-80.

Скакун Леонід Миколайович - кандидат медичних наук, доцент кафедри хірургічної стоматології Тернопільського національного медичного університету імені І. Я. Горбачевського МОЗ України; тел.: +38(0352) 26-82-80.

Галайчук Ігор Йосифович - доктор медичних наук, професор, завідувач кафедри онкології, променевої діагностики і терапії та радіаційної медицини Тернопільського національного медичного університету імені І. Я. Горбачевського МО3 України; тел.: +38(0352) 26-82-80. 